\title{
An Empirical Study on the Influence of School Choice on Junior Middle School Students' Academic Performance
}

\author{
Chenchen Fang \\ Beijing Normal University, Beijing 100875, China
}

\begin{abstract}
Using data from 17,424 junior middle school student responses in the Chinese Education Panel Survey 2014 (CEPS 2014), this study analyzes the influence of school choice on the academic performance of primary to junior students. The results show that students whose families have a higher socioeconomic status and urban students are more likely to choose their school, and that the student's choice of school does not make an impact on their Chinese, mathematics, foreign language or total academic scores. This indicates that choosing schools does not improve students' academic performance. School choice increases the unequal distribution of high-quality education opportunities and reduces the efficiency of educational resources. Therefore, the government should take measures to allocate quality resources more equitably, to increase the supply of quality education resources and to guide parents and students to choose schools rationally.
\end{abstract}

Best Evid Chin Edu 2019; 1(1):29-40.

Doi: 10.15354/bece.19.ar1010

Keywords: Primary-to-junior; School Choice on Junior Middle School; Students' Academic Performance; Education Equity

Correspondence to: Chenchen Fang, Doctoral Candidate, Institute of Educational Economics, Faculty of Education, Beijing Normal University, China, E-mail: fcc1121@163.com.

Conflict of Interests: None. 


\section{Research Background and Problem}

66 SCHOOL choice" has always been a factor contributing to unfair educational starts and opportunities in China. According to China's compulsory education law, children and teenagers within the compulsory education age range should attend the school nearby their domicile seat. If parents and children are working or residing in a place other than the domicile, the children's compulsory education should be received in the vicinity of their parents or other legal guardians. However, the development of compulsory education in China has been historically unbalanced and insufficient. High-quality education resources are limited, and families in higher social strata tend to acquire better education resources for their child through school choice, a behavior that increases the stratification perpetuated by education. In China, the government has clearly stated that multiple measures are necessary to resolve the inequities brought about by school choice. Although local governments have introduced various policies and measures to limit school choice, school choice is hardly prohibited. School choice not only brings an economic burden to the family, but also has an impact on the efficiency and fairness of compulsory education (Hu et al., 2008). The fundamental goal of parents and students when choosing a school is to gain a competitive advantage in college entrance examinations by attending a school that provides high quality educational resources and thereby significantly improves the students' academic achievement.

This leads to two questions: What factors affect students' school choice behavior? Can students improve their academic achievement through school choice? Using data from the 2014 China Education Panel Survey, this study analyzes the differences in the likelihood of making a school choice for students with different family backgrounds in China, and then estimates the effect of school choice on the academic achievement of junior high school students.

\section{Data Sources and Variable Descriptions}

All data used in this study are from the China Education Panel Survey (CEPS) conducted by the China Survey and data Center (NSRC) in 2014. The survey project selected 112 schools, 438 classes and approximately 20,000 junior middle-school students nationwide as a sample, and respondents in this study. Variables used in this study are described in Table $\mathbf{1 .}$

\section{Who is Choosing a School?}

School choice is examined by asking parents the multiple choice question: "Has your family done the following things in order to let children go to this school?" Figure 1 shows that $13.8 \%$ of parents seek help from friends, $1.9 \%$ give gifts to the leaders concerned, $2.9 \%$ pay extra fees, $5.5 \%$ buy houses in the school area, $3.1 \%$ 


\section{Table 1. Description of Variables.}

\begin{tabular}{|c|c|c|}
\hline Variable Type & Variable Name & Variable Description \\
\hline School Choice & School Choice or not & $0=$ No, $1=$ Yes \\
\hline \multirow{4}{*}{$\begin{array}{l}\text { Student Academic } \\
\text { Achievement }\end{array}$} & Total Grades & $\begin{array}{l}\text { The total grades of Language, Mathematics and } \\
\text { Foreign language in the mid-term exam of } 2013\end{array}$ \\
\hline & Language Grades & $\begin{array}{l}\text { Students' Language Grades in the mid-term exami- } \\
\text { nation of } 2013\end{array}$ \\
\hline & Mathematics Grades & $\begin{array}{l}\text { Students' Mathematics Grades in the mid-term ex- } \\
\text { amination of } 2013\end{array}$ \\
\hline & $\begin{array}{l}\text { Foreign language } \\
\text { Grades }\end{array}$ & $\begin{array}{l}\text { Students' Foreign language Grades in the mid-term } \\
\text { examination of } 2013\end{array}$ \\
\hline \multirow{4}{*}{ Individual Factors } & Gender & $0=$ Female, $1=$ Male \\
\hline & Only Child or Not & $0=$ No, $1=$ Yes \\
\hline & Migrant Child or Not & $0=$ No, $1=$ Yes \\
\hline & $\begin{array}{l}\text { Household Registration } \\
\text { Type }\end{array}$ & $0=$ Non-agricultural, $1=$ Agricultural \\
\hline \multirow{3}{*}{ Family Factors } & $\begin{array}{l}\text { Parental Education } \\
\text { Level * }\end{array}$ & $\begin{array}{l}\text { 1.Illiterate/Semi-literate, 2.Elementary School, } \\
\text { 3.Junior High School, 4.High School, } \\
\text { 5. Junior College, 6. undergraduate, } \\
\text { 7. Postgraduate and above }\end{array}$ \\
\hline & $\begin{array}{l}\text { Parental Occupation } \\
\text { Classification } \dagger\end{array}$ & 1. Lower, 2. Middle, 3. Upper \\
\hline & $\begin{array}{l}\text { Family Economic Sta- } \\
\text { tus }\end{array}$ & 1. Poor, 2. Medium, 3. wealthy \\
\hline \multirow{3}{*}{ School Factors } & School Region & $1=$ Eastern, $2=$ Central, $3=$ Western \\
\hline & School Location & $\begin{array}{l}1=\text { Central urban area, } 2=\text { Urban-rural Junction, } 3= \\
\text { Rural Area (Including Townships) }\end{array}$ \\
\hline & School Ranking & $\begin{array}{l}\text { 1=Blow the Middle level, } 2=\text { Middle and above, } \\
3=\text { Best }\end{array}$ \\
\hline \multicolumn{3}{|c|}{$\begin{array}{l}\text { *. Compare the educational level of father and mother and choose the higher one. } \\
\text { t. According to the study of Li Chunling (2010), divide the career of students' parents into upper, middle and } \\
\text { lower levels. }\end{array}$} \\
\hline
\end{tabular}

relocate their household registration, $1.2 \%$ attach their household registration to relatives or friends, $6.6 \%$ of parents let their children take all kinds of academic examinations/specialty examinations. In addition, $1.8 \%$ of parents choose schools by other methods. Overall, 26.8\% of junior high school students enter their school through at least one way of choosing a school, indicating that more than a quarter of junior high school students in China are school-choice students.

In addition, school choice behavior among junior high school students in China differs significantly based on the students' individual, family and school backgrounds. Table 2 shows that, at the individual level, gender significantly affects school choice behavior. The proportion of males that choose their school is $28.8 \%$, significantly higher than that of females at $24.7 \%$. The proportion of only-children making a school choice is $27.6 \%$, significantly higher than that of non-only children at $26.1 \%$. Significantly more migrant children choose their school than non-migrant children $(38.8 \%$ compared to $24.1 \%$, respectively). The proportion of non-agricultural household stu- 


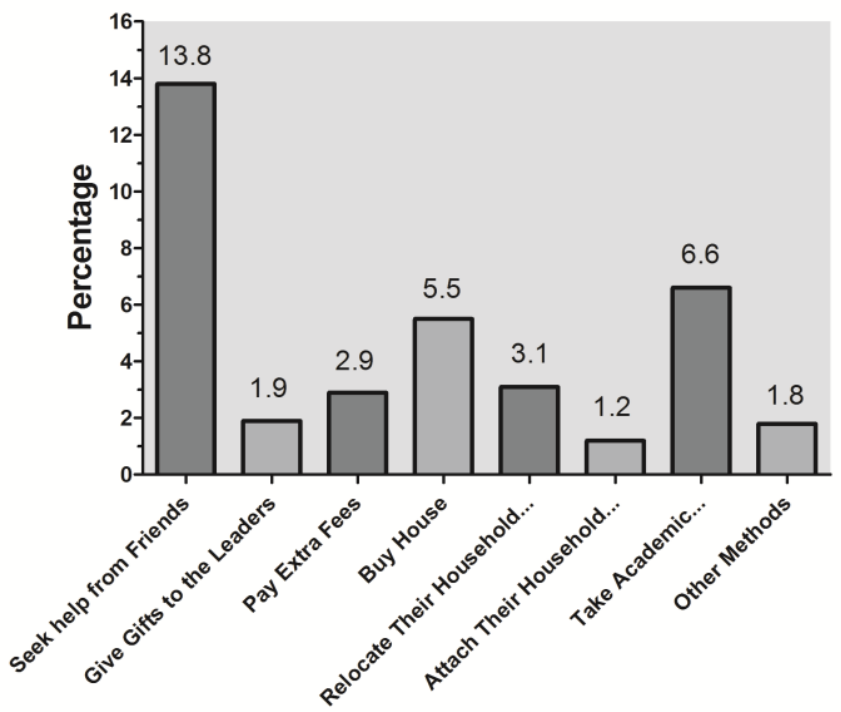

dents choosing their school is significantly higher at $28.5 \%$ compared to $25.3 \%$ of agricultural household students.

At the family level, the proportion of students choosing their school differs depending on parental educational level. Generally speaking, the higher the educational level of the parents, the greater the proportion of students that choose their school. The proportion of students making a school choice whose parental occupation classification is at the upper level is $31.7 \%$, significantly higher than students whose parental occupation classification is at the middle level $(27.3 \%)$ and students whose parental occupation classification is at the lower level $(20.4 \%)$. The proportion of students choosing schools is also significantly affected by family economic status. In students with a wealthy family economic status, $33.9 \%$ choose their school, significantly higher than for students with a medium family economic status $(26.8 \%)$ and students with a poor family economic status $(24.5 \%)$. In other words, the higher the family economic status is, the greater the proportion of students choosing their school.

At the school level, the proportion of students in schools of their own choosing occurs in the western region, at $31.8 \%$, followed by the eastern region at $27.6 \%$, and the central region has the lowest proportion at $18.9 \%$. There are significant differences in the proportion of students choosing schools in different regions. The highest proportion of students choosing their school is $31.8 \%$ in central urban areas, followed by $28.3 \%$ in the urban-rural junctions, and $20.3 \%$ in rural areas (including townships). The proportion of students who ranked below the middle level $(25.3 \%)$ or in the middle and above 


\section{Table 2. Differences in School Choice Scale of Students.}

\begin{tabular}{|c|c|c|c|}
\hline Variable & & $\begin{array}{l}\text { School Choice } \\
\text { Ratio }\end{array}$ & $\begin{array}{l}\text { Chi-Square } \\
\text { Test }\end{array}$ \\
\hline \multirow{2}{*}{ Gender } & Female & $24.7 \%$ & \multirow{2}{*}{$\begin{array}{l}x^{2}=39.315 \\
p<0.001\end{array}$} \\
\hline & Male & $28.8 \%$ & \\
\hline \multirow{2}{*}{ Only Child or Not } & No & $26.1 \%$ & \multirow{2}{*}{$\begin{array}{l}x^{2}=4.836 \\
p=0.028\end{array}$} \\
\hline & Yes & $27.6 \%$ & \\
\hline \multirow{2}{*}{ Migrant Child or Not } & No & $24.1 \%$ & \multirow{2}{*}{$\begin{array}{l}x^{2}=291.668 \\
p<0.001\end{array}$} \\
\hline & Yes & $38.8 \%$ & \\
\hline \multirow{2}{*}{$\begin{array}{l}\text { Household Registration } \\
\text { Type }\end{array}$} & Non-agricultural & $28.5 \%$ & \multirow{2}{*}{$\begin{array}{l}x^{2}=23.467 \\
p<0.001\end{array}$} \\
\hline & Agricultural & $25.3 \%$ & \\
\hline \multirow{7}{*}{$\begin{array}{l}\text { Parental Education } \\
\text { Level }\end{array}$} & Illiterate/semi-illiterate & $30.4 \%$ & \multirow{7}{*}{$\begin{array}{l}x^{2}=42.856 \\
p<0.001\end{array}$} \\
\hline & Elementary School & $25.4 \%$ & \\
\hline & Junior High School & $25.5 \%$ & \\
\hline & High School & $26.5 \%$ & \\
\hline & Junior College & $31.1 \%$ & \\
\hline & Undergraduate & $31.1 \%$ & \\
\hline & Postgraduate and above & $31.0 \%$ & \\
\hline \multirow{3}{*}{$\begin{array}{l}\text { Parental Occupation Clas- } \\
\text { sification }\end{array}$} & Lower & $20.4 \%$ & \multirow{3}{*}{$\begin{array}{l}x^{2}=142.519 \\
\mathrm{p}<0.001\end{array}$} \\
\hline & Middle & $27.3 \%$ & \\
\hline & Upper & $31.7 \%$ & \\
\hline \multirow{3}{*}{ Family Economic Status } & Poor & $24.5 \%$ & \multirow{3}{*}{$\begin{array}{l}x^{2}=38.440 \\
p<0.001\end{array}$} \\
\hline & Medium & $26.8 \%$ & \\
\hline & Wealthy & $33.9 \%$ & \\
\hline \multirow{3}{*}{ School Region } & Eastern & $27.6 \%$ & \multirow{3}{*}{$\begin{array}{l}x^{2}=186.044 \\
p<0.001\end{array}$} \\
\hline & Central & $18.9 \%$ & \\
\hline & Western & $31.8 \%$ & \\
\hline \multirow{3}{*}{ School area } & Central Urban Area & $31.8 \%$ & \multirow{3}{*}{$\begin{array}{l}x^{2}=242.029 \\
p<0.001\end{array}$} \\
\hline & Urban-rural Junction & $28.3 \%$ & \\
\hline & $\begin{array}{l}\text { Rural Area (Including Town- } \\
\text { ships) }\end{array}$ & $20.3 \%$ & \\
\hline \multirow{3}{*}{ School Ranking } & Below the middle level & $25.3 \%$ & \multirow{3}{*}{$\begin{array}{l}x^{2}=104.559 \\
p<0.001\end{array}$} \\
\hline & Middle and Above & $24.9 \%$ & \\
\hline & Best & $32.9 \%$ & \\
\hline
\end{tabular}

level $(24.9 \%)$, are similar but are significantly smaller than the proportion of students choosing their school who ranked best (32.9\%).

\section{What Factors Affect Students' School Choice?}

To explore the factors affecting students' school choice, we analyzed the factors that influence a student's decision to choose a school at the level of the individual, family and school:

$$
\mathrm{Y} 1=f(\mathrm{I}, \mathrm{F}, \mathrm{S})
$$

In model (1), Y1 represents whether students choose their school, a dichotomous variable. If students have at least one school choice behavior at the beginning of ele- 
mentary school, they are assigned a value of 1; otherwise they are assigned a value of 0 . I represents the individual factors of students, including student gender, whether they are an only child, whether they are migrant children and the type of household registration. F represents student family factors, including parental educational level, parental occupation classification and family economic status. S represents school factors, including school region, school location and school ranking.

In the specific analysis, a logistic regression model is used to explore the factors affecting whether students choose a school. Table 3 shows that after controlling for other factors, the probability of school choice is significantly lower in females than in males. Similarly, an only child is less likely to make a school choice than the non-only child. The probability of migrant children choosing their school is significantly higher than that of non-migrant children. Children with parents that had a higher occupation classification were more likely to make a school choice. In addition, controlling for other factors, the probability of choosing a school is significantly higher in the western compared to the eastern region, and in the eastern compared to the central region. The probability of students choosing their school in central urban areas and in urban-rural junction areas is significantly higher than that of students in rural area (including townships) choosing their school. School ranking has a significant positive impact on students' school choice. In cases of agricultural household registration, parental education level and family economic status have no significant impact on students' school choice.

\section{An Empirical Analysis of the Influence of School Choice on Students' Academic Performance}

To analyze the influence of school choice on student achievement, the classical theoretical model of the educational production function established by Hanushek was used to analyze the factors influencing student achievement (Hanushek, 1986). The extended theoretical model is established as follows:

$$
\mathrm{Y} 2=f(\mathrm{Z}, \mathrm{I}, \mathrm{F}, \mathrm{S})
$$

In model (2), Y2 represents student achievement, including language grades, mathematics grades, foreign language grades and total grades. $\mathrm{Z}$ represents whether students chose their school. I represents individual student factors, including gender, whether they are only children, whether they are migrant children and household registration type. F represents student family factors, including parental education level, parental occupational classification and family economic status. S represents school factors, including school region, school location and school ranking.

Table 4 shows that when controlling for other factors, school choice has a significant negative effect on students' academic achievement, both for individual subject grades and for total grades; that is, school choice cannot improve students' academic achievement. For both single subject grades and total grades, female students' academic achievement is significantly higher than that of males. The only child's academic 


\section{Table 3. Analysis of Factors Affecting Students' School Choice.}

\begin{tabular}{|c|c|c|}
\hline Variable & Coefficient & $\begin{array}{l}\text { Occurrence } \\
\text { Ratio } \\
(\operatorname{Exp}(B))\end{array}$ \\
\hline Female (referenced against male students) & $-0.224^{* \star *}(0.035)$ & 0.800 \\
\hline Only Child (referenced against non-only child) & $-0.127^{\star \star}(0.041)$ & 0.881 \\
\hline Migrant Children (referenced against non-migrant children) & $0.626^{* * *}(0.046)$ & 1.871 \\
\hline $\begin{array}{l}\text { Agricultural Household Registration (referenced against non- } \\
\text { agricultural) }\end{array}$ & $0.035(0.043)$ & 1.036 \\
\hline Parental Education level & $-0.013(0.019)$ & 0.987 \\
\hline Parental occupation Classification & $0.156^{\star \star \star}(0.033)$ & 1.169 \\
\hline Family Economic Status & $0.045(0.038)$ & 1.046 \\
\hline Central (referenced against Eastern region) & $-0.246^{\star * *}(0.052)$ & 0.782 \\
\hline Western (referenced against Eastern region) & $0.221^{* * *}(0.042)$ & 1.247 \\
\hline $\begin{array}{l}\text { Urban-rural junction (referenced against rural areas (Includ- } \\
\text { ing townships)) }\end{array}$ & $0.252^{\star \star \star}(0.049)$ & 1.287 \\
\hline $\begin{array}{l}\text { Central urban area (referenced against rural areas (Including } \\
\text { townships) ) }\end{array}$ & $0.361^{* * *}(0.052)$ & 1.435 \\
\hline School ranking & $0.164^{\star * \star}(0.030)$ & 1.178 \\
\hline Nagelkerke $\mathrm{R}^{2}$ & 0.052 & \\
\hline Sample Size & 17,424 & \\
\hline \multicolumn{3}{|c|}{ Notes: 1. Standard errors are in parentheses. $2 .{ }^{*} p<0.05,{ }^{* *} p<0.01,{ }^{* * *} p<0.001}$. \\
\hline
\end{tabular}

achievement is also significantly higher than that of the non-only child. In contrast, migrant children and non-migrant children did not differ significantly in achievement. Besides foreign language, the grades of agricultural household registration students are significantly higher than that of non-agricultural students. The higher the parental education level, the higher the parental occupation classification is and thus the better the financial status of the family is; this results in better student academic achievement. The language and foreign language grades of students in urban-rural junctions are significantly higher than those in rural areas (including townships), but do not differ significantly for other subject grades. Achievements of students in central urban areas are significantly higher than those in rural areas (including townships). The higher the ranking of schools, the better the students' academic achievements are.

\section{Conclusions}

Based on data from China Education Panel Survey done in 2014, this study analyzes differences in the proportion of students making a school choice at the primary-tojunior levels and its influence on subsequent academic achievement. The main conclusions are as follows. 
Table 4. The Results of Analysis on The Influence of School Choice on Junior Middle School Students' Academic Performance.

\begin{tabular}{|c|c|c|c|c|}
\hline Variable & $\begin{array}{l}\text { Model 1: } \\
\text { language } \\
\text { grades }\end{array}$ & $\begin{array}{l}\text { Model 2: } \\
\text { mathematics } \\
\text { grades }\end{array}$ & $\begin{array}{l}\text { Model 3: } \\
\text { foreign lan- } \\
\text { guage grades }\end{array}$ & $\begin{array}{l}\text { Model 4: } \\
\text { Total } \\
\text { grades }\end{array}$ \\
\hline School choice & $\begin{array}{l}-1.738^{* * *} \\
(0.333)\end{array}$ & $\begin{array}{l}-2.318^{\star * \star} \\
(0.526)\end{array}$ & $\begin{array}{l}-1.794^{\star * \star} \\
(0.479)\end{array}$ & $\begin{array}{l}-5.858^{\star * \star} \\
(1.185)\end{array}$ \\
\hline $\begin{array}{l}\text { Female (referenced against male stu- } \\
\text { dents) }\end{array}$ & $\begin{array}{l}7.986^{* * *} \\
(0.290)\end{array}$ & $\begin{array}{l}3.483^{* * *} \\
(0.459)\end{array}$ & $\begin{array}{l}13.042^{* * *} \\
(0.417)\end{array}$ & $\begin{array}{l}24.229^{* * *} \\
(1.033)\end{array}$ \\
\hline $\begin{array}{l}\text { Only Child (referenced against non- } \\
\text { only child) }\end{array}$ & $\begin{array}{l}2.589^{\star \star \star} \\
(0.339)\end{array}$ & $\begin{array}{l}3.807^{\star * \star} \\
(0.536)\end{array}$ & $\begin{array}{l}4.589^{\star * \star} \\
(0.487)\end{array}$ & $\begin{array}{l}10.849^{\star \star \star} \\
(1.207)\end{array}$ \\
\hline $\begin{array}{l}\text { Migrant Children (referenced against } \\
\text { non-migrant children) }\end{array}$ & $\begin{array}{l}1.091^{* *} \\
(0.410)\end{array}$ & $\begin{array}{l}0.270 \\
(0.648)\end{array}$ & $\begin{array}{l}1.074 \\
(0.590)\end{array}$ & $\begin{array}{l}2.401 \\
(1.461)\end{array}$ \\
\hline $\begin{array}{l}\text { Agricultural Household Registration } \\
\text { (referenced against non-agricultural) }\end{array}$ & $\begin{array}{l}1.627^{\star \star \star} \\
(0.351)\end{array}$ & $\begin{array}{l}1.949^{* * *} \\
(0.554)\end{array}$ & $\begin{array}{l}0.723 \\
(0.504)\end{array}$ & $\begin{array}{l}4.193^{* \star *} \\
(1.250)\end{array}$ \\
\hline Parental Education level & $\begin{array}{l}1.831^{\star \star *} \\
(0.157)\end{array}$ & $\begin{array}{l}3.643^{* * *} \\
(0.248)\end{array}$ & $\begin{array}{l}3.650^{\star \star *} \\
(0.226)\end{array}$ & $\begin{array}{l}9.134^{\star * \star} \\
(0.560)\end{array}$ \\
\hline Parental occupation Classification & $\begin{array}{l}1.252^{\star * *} \\
(0.270)\end{array}$ & $\begin{array}{l}1.651^{* * *} \\
(0.427) \\
\end{array}$ & $\begin{array}{l}2.427^{\star \star *} \\
(0.388) \\
\end{array}$ & $\begin{array}{l}5.337^{* * *} \\
(0.962) \\
\end{array}$ \\
\hline Family economic status & $\begin{array}{l}1.708^{* \star *} \\
(0.378) \\
\end{array}$ & $\begin{array}{l}1.008^{*} \\
(0.493)\end{array}$ & $\begin{array}{l}1.613^{* * *} \\
(0.448) \\
\end{array}$ & $\begin{array}{l}4.310^{* * *} \\
(1.110) \\
\end{array}$ \\
\hline $\begin{array}{l}\text { Central (referenced against Eastern } \\
\text { region) }\end{array}$ & $\begin{array}{l}-0.981^{*} \\
(0.312)\end{array}$ & $\begin{array}{l}-7.848^{* \star *} \\
(0.634)\end{array}$ & $\begin{array}{l}-1.336^{*} \\
(0.577)\end{array}$ & $\begin{array}{l}10.130^{* * *} \\
(1.429)\end{array}$ \\
\hline $\begin{array}{l}\text { Western (referenced against Eastern } \\
\text { region) }\end{array}$ & $\begin{array}{l}3.419^{* * *} \\
(0.364)\end{array}$ & $\begin{array}{l}-1.416^{\star} \\
(0.575)\end{array}$ & $\begin{array}{l}8.251^{* * *} \\
(0.523)\end{array}$ & $\begin{array}{l}10.340^{\star \star *} \\
(1.296)\end{array}$ \\
\hline $\begin{array}{l}\text { Urban-rural junction (referenced } \\
\text { against rural areas (Including town- } \\
\text { ships)) }\end{array}$ & $\begin{array}{l}0.858^{*} \\
(0.402)\end{array}$ & $\begin{array}{l}-0.458 \\
(0.636)\end{array}$ & $\begin{array}{l}2.269^{* * *} \\
(0.578)\end{array}$ & $\begin{array}{l}2.553 \\
(1.432)\end{array}$ \\
\hline $\begin{array}{l}\text { Central urban area (referenced against } \\
\text { rural areas (Including townships) ) }\end{array}$ & $\begin{array}{l}4.438^{* * *} \\
(0.430)\end{array}$ & $\begin{array}{l}4.069^{* * *} \\
(0.679)\end{array}$ & $\begin{array}{l}7.106^{* * *} \\
(0.618)\end{array}$ & $\begin{array}{l}15.711^{* * *} \\
(1.530)\end{array}$ \\
\hline School Ranking & $\begin{array}{l}2.072^{\star \star \star} \\
(0.507) \\
\end{array}$ & $\begin{array}{l}5.317^{* * *} \\
(0.402) \\
\end{array}$ & $\begin{array}{l}4.465^{\star * *} \\
(0.365) \\
\end{array}$ & $\begin{array}{l}11.759^{* \star *} \\
(0.905)\end{array}$ \\
\hline Adjusted $\mathrm{R}^{2}$ & 0.121 & 0.098 & 0.184 & 0.155 \\
\hline Sample Size & 17,020 & 17,012 & 17,013 & 16,975 \\
\hline
\end{tabular}

1. In China, the phenomenon of school choice remains widespread. Among all students surveyed, 26.8\% made a school choice. Among these, the proportion choosing a school by power, such as seeking help from friends, was the highest, accounting for $13.8 \%$ of students surveyed. Other methods of making a school choice were: choosing a school by score, such as relying on study and expertise, accounts for $6.6 \%$; choosing a school by house, such as buying a house in a school district, accounts for 5.5\%; choosing school by household, such as relocating household registration, relocating to relatives or friends' home accounts for $4.3 \%$; choosing school by money, such as paying additional expenses, accounts for $2.9 \%$; choosing school by power and money such as giving gifts to leaders accounts for $1.9 \%$; and $1.8 \%$ of parents choose schools by other means. 
2. The proportion of students choosing their school varies depending on individual, family and school backgrounds. The proportion of males choosing their school is higher than that of females. The proportion of only children choosing their school is higher than that of non-only children. The proportion of migrant children choosing their school is higher than that of non-migrant children. The proportion of agricultural children in a school of their choice is significantly higher than that of non-agricultural children. The better the family's socio-economic status is (parental education level, parental occupation classification, and family economic status), the greater the proportion of students that make a school choice. The proportion of students choosing schools in urban areas is significantly higher than that in rural areas. The proportion of students' choosing schools in the best-ranked schools is higher than the students in the middle and lower schools.

3. Whether students choose their school is mainly influenced by three levels of factors: individual, family and school. When controlling other factors, the probability of school choice for an only child is significantly lower than that of a non-only child. The probability of school choice among migrant children is significantly higher than among non-migrant children. Among family factors, parental occupation classification has a significant positive impact on the likelihood of school choice. Parental education level and family economic status have no significant effects. Among school factors, the probability of school choice of students in urban areas is significantly higher than that of students in rural areas. School ranking has a significant positive impact on the possibility of students choosing school. The higher the school ranks, the higher the probability of students will choose school.

4. Based on the classic theoretical model of educational production function established by Hanushek, the regression model was used to explore the influence of school choice behavior of "primary-to-junior" on students' academic achievement. It was found that after controlling for individual, family, school and other influencing factors, students' choice of school has a significant negative impact on academic achievement. School choice does not improve students' academic achievement.

\section{Discussion}

School choice in China is a common phenomenon, and there are profound cultural, educational, economic and political reasons behind it. From the perspective of cultural reasons, China has been deeply influenced by Confucian culture. The concepts of Confucian culture that promote paying more attention to education clearly have an important influence on school choice behavior. From the perspective of education, students decide to choose their school in order to obtain better quality educational resources. At present, China's education system remains dominated by examinations. Students can obtain high-quality educational resources by choosing schools, and then gain advantages in entrance examinations. From an economic standpoint, parents wanting to invest more in their children's education choose a school to gain higher returns. If school choice enables students to receive higher 
levels of education in the future and increases the rate of return on education, then it is wise for students to choose their school. Raftery's Maximally Maintained Inequality Hypothesis (MMI) (Raftery \& Hout, 1993) and Lucas's Effectively Maintained Inequality (EMI) (Lucas \& Samuel, 2001) model provide good explanations of political reasons for school choice. According to MMI theory, when compulsory education is not fully universal, educational opportunities for children from different family strata are different. Parents with higher socio-economic status are always looking for ways to maximize their children's educational opportunities. Only when the demand for education reaches saturation, can the difference in enrollment opportunities between upper and lower status families be reduced. According to EMI theory, when compulsory education is popularized, there is a gap in the quality of education between regions, between urban and rural areas, and between schools. The current unbalanced development of compulsory education in China puts the core of competition not for the opportunity to receive education, but for the quality of education, and school choice is the specific manifestation of this competition. Families with higher socio-economic status choose schools to help their children obtain higher quality education, and thereby help their children to gain advantages in future education and employment. This effectively maintains educational inequality and the family's current social status, as well as the social status of future generations. This also explains why the proportion of students from families with higher socioeconomic status choosing their school is significantly higher than that of students from families with lower socioeconomic status. Compared with rural areas, the education level in urban areas is higher and the differences between schools are larger. As the quality of education has become the core of competition, the proportion of students in urban areas choosing their school is higher than that in rural areas.

Families with higher socio-economic status and students from urban areas are more likely to choose their schools, which show that school choice has the function of social reproduction. To some extent, it also reflects educational inequality and social inequality. In addition, it is a concrete manifestation of the gap between the wealthy and the poor, and the urban and the rural areas. With the popularization of compulsory education, although differences in access to education among children from different classes of families are gradually decreasing, there are still gaps in access to education quality. School choice may lead to differences in students' academic achievement and job opportunities in the future, which consequently maintains society strata and hinders intergenerational mobility.

The main reason students choose their school is to obtain high-quality educational resources and improve their academic performance. However, this study finds that school choice does not improve students' academic achievement, regardless of whether considering a single subject or total grades. High-quality schools may gather excellent teachers and resources, which may affect students' learning attitude and behavior, but this does not have a direct and significant effect on students' academic achievements. 


\section{Recommendations}

1. The government should take active measures to control school choice behavior and allocate high-quality educational resources more equitably, so that children across all socioeconomic strata can have high-quality educational resources. If school choice behavior continues unchecked, higher quality educational resources will only be available to students from families of higher socioeconomic status. However, the use of high-quality educational resources is inefficient for the higher socio-economic families, which reduces the overall efficiency of the use of educational resources. Therefore, only by regulating school choice behavior can highquality educational resources play a greater role, thereby improving the overall efficiency of the use of educational resources, the quality of education, and educational equity.

2. The government should increase the supply of high-quality educational resources, alleviate parents' demand for school choice, promote the balanced development of compulsory education effectively, and narrow the quality and condition gap among regions, between urban and rural areas, among schools. The current "school choice fever" is indicative of a shortage of high-quality educational resources, whereby people's demand for quality education is greater than the supply of quality schools. Therefore, the government should continue to increase the number of high-quality schools by means of precise support to reasonably solve the expectations and demands of parents and society for high-quality educational resources, should better integrate educational resources, and should increase support for economically backward areas and weak schools to promote the balanced development of compulsory education and reduce the demand for school choice.

3. The government should guide parents and students from different socioeconomic strata in urban and rural areas to treat school choice rationally. In particular, families should be made aware that choosing a particular school does not lead to higher achievement benefits for students. Further, for those areas and families experiencing poor economic conditions, school choice creates a heavier financial burden.

\section{References}

Hu, Y. M., Lu, K., \& Xue, H.Y. (2008) An Empirical Study on School Choice in Primary and Secondary Schools. J Edu Stud; 2:74-78.

Hanushek, E. A. (1986) The economics of schooling: production and efficiency in public schools. J Econ Lit; 24(3):1141-1177.

Raftery, A. E., \& Hout, M. (1993) Maximally maintained inequality: expansion, reform, and opportunity in irish education, 1921-75. Sociol Edu; 66(1):41-62.

Lucas, \& Samuel, R. (2001) Effectively maintained inequality: education transitions, track mobility, and social background effects. Am J Sociol; 106(6):1642-1690. 
Received: 10 November 2018

Revised: 22 December 2018

Accepted: 23 December 2018

The Chinese version of this article has been published in the Journal of Inner Mongolia Normal University (Philosophical \& Social Science) 2018; 47(3):96-102. The English version has been authorized for being publication in BECE by the author(s) and the Chinese journal.

方晨晨. 小开初择校对学生成绩影响的实证研究. 内蒙古师范大学学报 (哲学社会科学版) 2018; 47(3):96-102. 